\title{
ALLOGENEIC PLATELET-RICH PLASMA FOR ROTATOR CUFF REPAIR
}

\section{PLASMA RICO EM PLAQUETAS ALOGÊNICO PARA REPARO DO MANGUITO ROTADOR}

\author{
Chris Hyunchul Jo ${ }^{1}$, Ji Sun Shin ${ }^{1}$, Seung Yeon Lee ${ }^{1}$, Sue Shin ${ }^{2}$ \\ 1. Seoul National University College of Medicine, SMG-SNU Boramae Medical Center, Department of Orthopedic Surgery, Seoul, Korea. \\ 2. Seoul National University College of Medicine, SMG-SNU Boramae Medical Center, Department of Laboratory Medicine, Seoul, Korea.
}

\section{ABSTRACT}

Objective: To investigate the safety and efficacy of allogeneic platelet-rich plasma (PRP) in rotator cuff repair. Methods: Seventeen patients with a full-thickness rotator cuff tear were included. Ten patients underwent arthroscopic rotator cuff repair with allogeneic, and seven patients with autologous PRP. Three PRP gels in a volume $3 \mathrm{ml}$ each were applied between the torn end and the greater tuberosity. Clinical outcomes were assessed preoperatively and at a minimum of 2 years after surgery. Structural outcomes were evaluated with the presence of retear and the change of the cross-sectional area (ACT) of the supraspinatus. Results: Allogeneic PRP did not cause any adverse events during the follow-up period. There was no significant difference in the clinical outcome measures between the two groups (all $p>0.05$ ). The retear rate was $33.3 \%$ and $25.0 \%$ in the allogeneic group and autologous group, respectively $(p=0.764)$. The change between the one-year postoperative and immediately postoperative ACT was not also significantly different between the two groups $(p=0.373)$. Conclusion: Allogeneic PRP in arthroscopic rotator cuff did not cause any local or general complications and that has the efficacy comparable to autologous PRP with respect to the clinical and structural outcomes. Level of Evidence III, Retrospective Comparative Study.

Keywords: Platelet-rich plasma. Rotator cuff. Growth factors. Tendon injuries.

\section{RESUMO}

Objetivo: Investigar a segurança e eficácia do plasma rico em plaquetas alogênico (PRP) no reparo do manguito rotador. Métodos: Foram incluídos dezessete pacientes com ruptura da espessura total do manguito rotador. Dez pacientes foram submetidos a reparo artroscópico do manguito rotador com PRP alogênico e sete pacientes com PRP autólogo. Três géis de PRP de $3 \mathrm{ml}$ cada foram aplicados entre a extremidade lesionada e a tuberosidade maior. Os resultados clínicos foram avaliados no pré-operatório e no mínimo 2 anos após a cirurgia. Os resultados estruturais foram avaliados com a presença de nova ruptura e a alteração da área em corte transversal (ACT) do supra-espinhal. Resultados: O PRP alogênico não causou quaisquer eventos adversos durante o período de acompanhamento. Não houve diferença significativa nas medidas de resultados clínicos entre os dois grupos (todos os valores $p>0,05$ ). A taxa de nova ruptura foi de 33,3\% e 25,0\% no grupo alogênico e grupo autólogo, respectivamente $(p=0,764)$. A alteração da ACT entre o pós-operatório de um ano e imediatamente no pós-operatório também não foi significativamente diferente entre os dois grupos ( $p=0,373)$. Conclusão: O PRP alogênico administrado por via artroscópica no manguito rotador não causou quaisquer complicações locais ou gerais e sua eficácia é comparável ao PRP autólogo no que diz respeito aos resultados clínicos e estruturais. Nível de Evidência III, Estudo Retrospectivo Comparativo.

Descritores: Plasma rico em plaquetas. Bainha rotadora. Fatores de crescimento. Traumatismos dos tendões.

Citation: Jo CH, Shin JS, Lee SY, Shin S. Allogeneic platelet-rich plasma for rotator cuff repair. Acta Ortop Bras. [online]. 2017;25(1):38-43. Available from URL: http://www.scielo.br/aob.

\section{INTRODUCTION}

Platelet-rich plasma (PRP) has recently been actively investigated in various injuries and diseases. ${ }^{1}$ While the effects of PRP in arthroscopic rotator cuff repair have also been reported by several authors, ${ }^{2-4}$ the results are still not conclusive. Most of the previous studies used autologous PRP, 1,5,6 but this plasma may not be available in certain patients such as patients with hematological diseases or who use anti-platelet medication, elderly patients with multiple comorbidities, patients who do not want to draw blood for any reason, and so on.7,8 Even though percutaneous local delivery of PRP improved fracture healing in diabetic rats, ${ }^{9}$ autologous PRP might not be an optimal solution since it has been reported that expression of platelet-derived growth factor decreased in diabetic animals. ${ }^{10}$ Therefore, an alternative to

All the authors declare that there is no potential conflict of interest referring to this article.

Study performed at Seoul National University College of Medicine, SMG-SNU Boramae Medical Center, Department of Orthopedic Surgery, Seoul, Korea Correspondence: SMG-SNU Boramae Medical Center, Seoul National University College of Medicine, Seoul, Korea. 07061. chrisjo@snu.ac.kr 
autologous PRP in these circumstances may be necessary, and allogeneic PRP is an option. Allogeneic platelets in the form of platelet concentrates have long been given safely in the treatment of thrombocytopenia or platelet dysfunction, or to patients with active platelet-related bleeding, or as prophylaxis in patients without cross-matching who are at serious risk of bleeding. Besides transfusion medicine, use of allogeneic PRP has only been described in a few case reports of oral and maxillofacial surgery. ${ }^{8,11,12}$ No study was found in the field of orthopedics except for one case report on the treatment of pseudoarthrosis of the distal tibia in a diabetic patient. ${ }^{8}$

The goal of this retrospective cohort study was to investigate the safety and efficacy of allogeneic PRP application in arthroscopic rotator cuff repair with regards to the clinical and structural outcomes. Our hypothesis was that allogeneic PRP was as safe and effective as autologous PRP.

\section{PATIENTS AND METHODS}

\section{Study design and patients}

This retrospective cohort study was approved by the hospital's institutional review board (IRB of Seoul National University Boramae Medical Center, No. 262015112). We investigated clinical and structural outcomes in patients who underwent arthroscopic rotator cuff repair with allogeneic PRP in comparison with patients who received autologous PRP. All allogeneic PRP was obtained from patients who underwent arthroscopic rotator cuff repair with autologous PRP on the same day. The inclusion criteria were full-thickness rotator cuff tear treated by arthroscopic rotator cuff repair with allogeneic PRP and minimum follow-up of 24 months.

From March 2009 to March 2011, 10 patients underwent arthroscopic rotator cuff repair with allogeneic PRP that was drawn and prepared from 8 patients who also underwent surgeries with autologous PRP on the same day; 4 with full-thickness rotator cuff tears and 3 with partial-thickness tears underwent rotator cuff repair, and 1 with a refracture of the clavicle and a metal failure received open reduction revision and internal plate fixation. Among the 10 patients who received allogeneic PRP, 6 received plasma from 6 different patients ( 5 with rotator cuff tears and 1 with a refracture), and the other 4 received plasma from 2 patients ( 2 from each one patient with a partial-thickness rotator cuff tear). Therefore, a total of 17 patients were included in the study: 10 in the allogeneic group, and 7 in the autologous group.

\section{Preparation of PRP}

PRP was obtained one day before surgery using a plateletpheresis system with a leukoreduction set (COBE Spectra LRS Turbo, Caridian BCT, Lakewood, Colorado) as previously described. ${ }^{2}$ An aliquot was used to determine complete blood counts using a fully automated analyzer (XE-2100, Sysmex Corporation, Kobe, Japan), and concentration of fibrinogen was assessed using an automated coagulation analyzer (CA-7000, Sysmex Corporation). For use in the rotator cuff repair, the platelet counts in the PRP were adjusted with saline to $1000 \times 10^{3}$ platelets per microliter. To produce a gel from the prepared PRP, $0.3 \mathrm{ml}$ of $10 \%$ calcium gluconate was added to 3 $\mathrm{ml}$ of PRP. The dilution and gelling procedure was performed within one hour of surgical application. ${ }^{2}$

To assess the safety of the allogeneic PRP, tests for hepatitis B (HBV), hepatitis $\mathrm{C}(\mathrm{HCV})$, human immunodeficiency virus $(\mathrm{HIV})$, and syphilis (VDRL) were performed and confirmed before application. ${ }^{12}$

\section{Surgical procedures and application of PRP}

Arthroscopic surgery and application of PRP were performed with patients in the lateral decubitus position under general anesthesia, as described previously. ${ }^{13,14}$ Three PRP gels per patient were threaded to the suture and introduced into the $5.5 \mathrm{~mm}$ cannula after medial row sutures were placed. With the PRP gels in place, medial row sutures were tied using a SP knot if necessary. ${ }^{15}$ The lateral row was then secured using suture anchors, and the PRP gels were interposed at the tendon-bone interface. The patient's shoulders were immobilized for four to six weeks using an abduction brace and then passive range of motion (ROM) and active assisted ROM exercises were gradually permitted. Patients began strengthening exercises after three months.

\section{Outcome assessments}

For the safety evaluation, general symptoms or signs related to immune responses such as fever, chills, pruritis, dyspnea, urticaria, or rash were observed. The wound site was also evaluated daily to determine the presence of zones of erythema, swelling, or abnormal discharge until patients were discharged from the hospital.

Clinical outcomes were assessed according to: 1) pain, 2) ROM, 3) muscle strength, 4) overall satisfaction, and 5) functional scores. To evaluate structural integrity, magnetic resonance imaging (Achieva 3.0-T, Philips Medical System, Eindhoven, The Netherlands) with a dedicated shoulder coil was performed at least 9 months after surgery. Structural integrity was evaluated using Sugaya's MRI classification for patients. ${ }^{16}$ All images were reviewed by a fellowship-trained musculoskeletal radiologist and an orthopedic surgeon. The change in the cross-sectional area (CSA) of the supraspinatus was calculated by subtracting measures of the two different time points. ${ }^{17-19}$ The statistical analysis was performed using SPSS version 13.0 (SPSS Inc., Chicago, IL), and the significance level was set at $p=0.05$ throughout.

\section{RESULTS}

\section{Baseline demographics \& adverse events}

All 17 patients were followed clinically for a minimum of 24 months. The average age was significantly higher in the allogeneic group $(63.57 \pm 9.61)$ than in the autologous group (56.33 \pm 7.45$)$, and there were more women in the allogeneic group (80.0\%) than in the autologous group (28.6\%). All patients in the allogeneic group had a full-thickness rotator cuff tear, while 3 of 7 (42.9\%) in the autologous group had a partial-thickness rotator cuff tear ( $p=0.023)$. The other characteristics did not differ significantly, as summarized in Table $1 .{ }^{20}$ No general or local adverse events with regard to allogeneic or autologous PRP usage were observed during the immediate postoperative or follow-up periods.

Characteristics of PRP with respect to concentration, activation, and method of application

The characteristics of the PRP used in this study are described using the CAM classification. ${ }^{21}$ (Table 2 ) The average platelet count increased from $256.71 \pm 72.04$ ( $\times 10^{3}$ platelets per microliter) in whole blood to $918.14 \pm 149.61$ in PRP, a 3.6-fold increase from the baseline $(p<0.001)$. The average red and white blood cell counts fell from $4.44 \pm 0.48$ to $0.15 \pm 0.07$ ( $\times 10^{3}$ cells per microliter), and from $5.59 \pm 0.68$ in whole blood to $0.02 \pm 0.01$, respectively, representing a 0.03 - and 0.004 -fold decrease from the baseline, respectively (all $p<0.001$ ). 
Table 1. Baseline demographics.

\begin{tabular}{|c|c|c|c|}
\hline & $\begin{array}{l}\text { Allogeneic } \\
(n=10)\end{array}$ & $\begin{array}{l}\text { Autologous } \\
(n=7)\end{array}$ & p-value \\
\hline Mean age, y & 63.579 .61 & 56.337 .45 & 0.029 \\
\hline Sex (male:female), $\mathrm{n}$ & $2: 8$ & $5: 2$ & 0.034 \\
\hline Side (right:left), $n$ & $8: 2$ & $5: 2$ & 0.682 \\
\hline Dominance (yes:no), $n$ & $7: 3$ & $5: 2$ & 0.949 \\
\hline Duration, mo & 14.4013 .02 & $21.71 \quad 19.46$ & 0.366 \\
\hline Aggravation, mo & 2.711 .38 & 3.423 .17 & 0.604 \\
\hline $\mathrm{fRCT}: \mathrm{pRCT}, \mathrm{n}$ & $10: 0$ & $4: 3$ & 0.023 \\
\hline None: SLAP I : SLAP $\|_{+}, \mathrm{n}$ & $7: 2: 1$ & $6: 0: 1$ & 0.450 \\
\hline SB tear grade $(0: 1: 2: 3)^{*}, n$ & $2: 6: 1: 1$ & 2:3:1:1 & 0.922 \\
\hline Biceps tear (none: partial : complete), $n$ & $6: 3: 1$ & $3: 3: 1$ & 0.784 \\
\hline Cofield type (P:S:M:L:MSV), $n$ & 0:1:5:3:1 & $3: 0: 1: 1: 2$ & 0.103 \\
\hline Boileau stage (l:II:III:IV), $\mathrm{n}$ & $4: 1: 4: 1$ & $3: 1: 1: 2$ & 0.614 \\
\hline Tendon grade $(A: B: C) \dagger, n$ & $1: 6: 3$ & $3: 3: 1$ & 0.279 \\
\hline Treatment (StoS: 1 row : 2 row), $n$ & $1: 1: 8$ & $2: 1: 4$ & 0.556 \\
\hline Labrum (none : debride : repair), $\mathrm{n}$ & $7: 3: 0$ & $6: 0: 1$ & 0.160 \\
\hline SB (none: debride : repair), $\mathrm{n}$ & $3: 5: 2$ & $2: 2: 3$ & 0.551 \\
\hline $\begin{array}{c}\text { Biceps (none: tenodesis : debride : } \\
\text { tenotomy), } \mathrm{n}\end{array}$ & 7:0:3 & $4: 1: 2$ & 0.464 \\
\hline Acromioplasty (yes:no), $n$ & $1: 9$ & $0: 7$ & 0.388 \\
\hline GT medialization (yes:no), $n$ & $1: 9$ & $2: 5$ & 0.323 \\
\hline GT coverage $(A: B: C: D) \ddagger, n$ & $4: 5: 0: 1$ & $3: 3: 1: 0$ & 0.536 \\
\hline
\end{tabular}

Fatty infiltration (0:1:2:3:4), $\mathrm{n}$

\begin{tabular}{c|c|c|c}
\hline Supraspinatus & $0: 5: 1: 2: 2$ & $3: 1: 1: 1: 1$ & 0.200 \\
\hline Infraspinatus & $1: 5: 2: 1: 1$ & $3: 2: 2: 0: 0$ & 0.423 \\
\hline Subscapularis & $4: 6: 0: 0: 0$ & $3: 3: 0: 1: 0$ & 0.435 \\
\hline GFID & 1.430 .88 & 1.050 .80 & 0.370 \\
\hline
\end{tabular}

Muscle atrophy

\begin{tabular}{c|c|c|c}
\hline Tangent (1:2:3), $\mathrm{n}$ & $6: 3: 1$ & $4: 3: 0$ & 0.638 \\
\hline Occupation ratio (1:2:3)\|, $\mathrm{n}$ & $4: 4: 2$ & $4: 1: 2$ & 0.519 \\
\hline Clinical follow-up, mo & 29.575 .97 & 28.295 .59 & 0.946 \\
\hline MRI follow-up, mo & 15.003 .94 & 10.501 .91 & 0.053 \\
\hline
\end{tabular}

"Subscapularis tear was graded according to the Nove-Josserand et al. ${ }^{20}$ Grade 0, normal tendon; grade 1 , tear less than one-quarter; grade 2, tear more than one-quarter but not complete; and grade 3, complete tear tTendon grade assesses rotator cuff quality using three gross tendon criteria; ${ }^{[14]}$ (1) fraying over half of the tendon thickness; (2) delamination of the supraspinatus tendon, and (3) thinning of less than half of the normal thickness. A, none of these criteria were met; B, fraying or delamination was identified; and C, both fraying and delamination or thinning regardless of the other criteria ${ }^{\mathrm{G}} \mathrm{GT}$ coverage evaluates the repair quality. $\mathrm{A}$, complete coverage of the original footprint; $B$, incomplete coverage more than half of the footprint; $C$, incomplete coverage less than half of the footprint; and D, the presence of defect into the glenohumeral joint ${ }^{\S}$ Tangent sign assesses muscle atrophy of the supraspinatus. Grade 1, negative, which means that the superior border of the supraspinatus was superior to the line tangential to the coracoid and scapular spine; grade 2, borderline, which means that the superior border was located about the tangential line; grade 3, positive, which means that the superior border was inferior to the tangential line. 'Occupation ratio means the ratio of the CSA of the supraspinatus to the fossa. Grade 1, 0.6 to 1 ; grade $2,0.4$ to 0.6 ; grade $3,<0.4$. fRCT a full-thickness rotato cuff tear, pRCT a partial-thickness rotator cuff tear, SLAP II+ superior labral anterior and posterior lesion 2 and above, SB subscapularis, P:S:M:L:MSV small:medium:large:massive, StoS side-to-side repair, GT greater tuberosity, GFDI global fatty degeneration index
Table 2. Characteristics of the Platelet-Rich Plasma used in the study with respect to concentration, activation, and method of application

\begin{tabular}{|c|c|c|c|c|}
\hline \multirow{2}{*}{ Concentration } & $\begin{array}{c}\text { Platelets, } \\
10^{3} / \mathrm{L}\end{array}$ & $\begin{array}{l}\text { WBC, } \\
10^{3} / L\end{array}$ & $\begin{array}{l}\text { RBC, } \\
10^{3} / \mathrm{L}\end{array}$ & Fibrinogen, $\mathrm{mg} / \mathrm{dL}$ \\
\hline & $\begin{array}{c}918.14 \pm \\
149.61\end{array}$ & $0.02 \pm 0.01$ & $0.15 \pm 0.07$ & NA \\
\hline \multirow{2}{*}{ Activation } & \multicolumn{2}{|c|}{ Activation status (\%)* } & \multicolumn{2}{|c|}{ Activation method } \\
\hline & \multicolumn{2}{|c|}{ NA } & \multicolumn{2}{|c|}{ calcium alone } \\
\hline \multirow{2}{*}{ Method } & State & Volume (ml) & Number & Interval (day) \\
\hline & gel & $3 \times 3$ & 1 & 0 \\
\hline
\end{tabular}

Data are expressed as average \pm standard deviation in concentration properties. *Activation status was measured using flow cytometry with $C D 61$ and $C D 62 P$ in five patients. Results were expressed by the percentage of $C D$ 62P-positive counts over CD 61-positive counts. WBC White blood cells, RBC Red blood cells, NA Not available

After surgery, all VAS pain measurements decreased significantly in both groups, and there were no significant differences between the two groups preoperatively or postoperatively. (Table 3) Representatively, average VAS pain measurements decreased from 5.41 \pm 2.19 to $0.49 \pm 0.69$ in the allogeneic group $(p<0.001)$, and from $3.50 \pm 1.97$ to $0.08 \pm 0.17$ in the autologous group $(p=0.010)$. Forward flexion, abduction, and internal rotation significantly increased while external rotation of the arm at the side did not increase in the allogeneic group. (Table 3) In the autologous group, external arm rotation at the side significantly increased, while forward flexion, abduction, and internal rotation did not. No significant differences were found between the two groups for active forward flexion, abduction, external arm rotation at the side, and internal rotation before and after surgery.

Supraspinatus strength improved significantly in the allogenic group, from $4.12 \pm 3.03 \mathrm{lb}$ to $8.06 \pm 2.60 \mathrm{lb}(p=0.016)$, but this was not the case for the autologous group, which showed a less notable improvement from $6.46 \pm 3.34 \mathrm{lb}$ to $9.31 \pm 4.55 \mathrm{lb}$ $(p=0.128)$. (Table 3 ) Infraspinatus strength did not significantly improve in either groups, increasing only slightly from $6.80 \pm 3.02 \mathrm{lb}$ to $7.93 \pm 2.05 \mathrm{lb}$ in the allogeneic group $(p=0.318)$ and from $6.41 \pm 2.96 \mathrm{lb}$ to $9.37 \pm 4.55 \mathrm{lb}$ in the autologous group $(p=0.088)$. Subscapularis strength improved significantly from $6.10 \pm 2.37$ $\mathrm{lb}$ to $11.29 \pm 3.77 \mathrm{lb}$ in the allogeneic group $(p=0.001)$, but not in the autologous group, which increased from $8.77 \pm 5.11 \mathrm{lb}$ to $13.90 \pm 5.84 \mathrm{lb}(p=0.138)$. The strength of the supraspinatus, infraspinatus, and subscapularis did not differ significantly in the two groups preoperatively or postoperatively.

Eight out of 10 patients (80.0\%) in the allogeneic group expressed willingness to undergo surgery again and wouldrecommend the surgery to other patients; in the autologous group this number was $6(85.7 \%)$ and 7 (100.0\%) out of 7 patients, respectively, showing no difference between the two groups. (Table 3) Overall function improved from $4.30 \pm 2.36$ to $8.57 \pm 1.51$ in the allogeneic group $(p$ $<0.001$ ), and from $5.67 \pm 1.21$ to $9.10 \pm 1.18$ in the allogeneic group $(p=0.001)$. Overall satisfaction was $88.57 \pm 13.45$ in the allogeneic group, and $92.14 \pm 9.06$ in the autologous group.

ASES, Constant, DASH, SST, and SPADI scores significantly improved after surgery, while the UCLA score did not improve in either group. (Table 4) No significant differences were found in all the scores between the two groups both preoperatively and postoperatively. 
Table 3. Pain, ROM, Strength and Overall Satisfaction

\begin{tabular}{|c|c|c|c|}
\hline Variable & Allogeneic $(n=10)$ & Autologous ( $\mathrm{n}=7$ ) & $p$-value \\
\hline \multicolumn{4}{|c|}{ Pain at rest } \\
\hline Preop & $4.10 \pm 1.66$ & $3.33 \pm 2.34$ & 0.455 \\
\hline Final & $0.29 \pm 0.76$ & $0.00 \pm 0.00$ & 0.219 \\
\hline $\mathrm{p}$-value & $<0.001$ & 0.017 & \\
\hline \multicolumn{4}{|c|}{ Pain in motion } \\
\hline Preop & $6.33 \pm 3.09$ & $4.00 \pm 2.37$ & 0.136 \\
\hline Final & $0.62 \pm 0.73$ & $0.10 \pm 0.16$ & 0.387 \\
\hline$p$-value & 0.001 & 0.011 & \\
\hline \multicolumn{4}{|c|}{ Pain at night } \\
\hline Preop & $5.80 \pm 2.78$ & $3.17 \pm 2.71$ & 0.086 \\
\hline Final & $0.57 \pm 0.79$ & $0.14 \pm 0.38$ & 0.331 \\
\hline$p$-value & 0.001 & 0.048 & \\
\hline \multicolumn{4}{|c|}{ Pain average } \\
\hline Preop & $5.41 \pm 2.19$ & $3.50 \pm 1.97$ & 0.102 \\
\hline Final & $0.49 \pm 0.69$ & $0.08 \pm 0.17$ & 0.317 \\
\hline$p$-value & $<0.001$ & 0.010 & \\
\hline \multicolumn{4}{|c|}{$\begin{array}{c}\text { Forward flexion, } \\
\text { deg }\end{array}$} \\
\hline Preop & $131.00 \pm 36.73$ & $165.71 \pm 29.36$ & 0.056 \\
\hline Final & $175.00 \pm 7.64$ & $174.29 \pm 7.87$ & 0.960 \\
\hline$p$-value & 0.005 & 0.448 & \\
\hline \multicolumn{4}{|c|}{ Abduction, deg } \\
\hline Preop & $122.00 \pm 45.59$ & $160.00 \pm 44.35$ & 0.108 \\
\hline Final & $174.29 \pm 15.12$ & $177.14 \pm 7.56$ & 0.658 \\
\hline$p$-value & 0.005 & 0.360 & \\
\hline \multicolumn{4}{|c|}{$\begin{array}{l}\text { External rotation } \\
\text { arm at side, deg }\end{array}$} \\
\hline Preop & $41.00 \pm 15.06$ & $45.71 \pm 14.56$ & 0.529 \\
\hline Final & $46.43 \pm 17.01$ & $58.57 \pm 16.26$ & 0.102 \\
\hline $\mathrm{p}$-value & 0.635 & 0.022 & \\
\hline \multicolumn{4}{|c|}{$\begin{array}{l}\text { Internal rotation, } \\
\text { vertebral level }\end{array}$} \\
\hline Preop & $7.70 \pm 3.86$ & $9.14 \pm 3.53$ & 0.445 \\
\hline Final & $11.57 \pm 1.40$ & $10.86 \pm 1.57$ & 0.628 \\
\hline $\mathrm{p}$-value & 0.020 & 0.127 & \\
\hline \multicolumn{4}{|c|}{ Supraspinatus, Ib } \\
\hline Preop & $4.12 \pm 3.03$ & $6.46 \pm 3.34$ & 0.154 \\
\hline Final & $8.06 \pm 2.60$ & $9.31 \pm 4.47$ & 0.679 \\
\hline$p$-value & 0.016 & 0.128 & \\
\hline \multicolumn{4}{|c|}{ Infraspinatus, lb } \\
\hline Preop & $6.80 \pm 3.02$ & $6.41 \pm 2.96$ & 0.797 \\
\hline Final & $7.93 \pm 2.05$ & $9.37 \pm 4.55$ & 0.421 \\
\hline$p$-value & 0.318 & 0.088 & \\
\hline \multicolumn{4}{|c|}{ Subscapularis, Ib } \\
\hline Preop & $6.10 \pm 2.37$ & $8.77 \pm 5.11$ & 0.165 \\
\hline Final & $11.29 \pm 3.77$ & $13.90 \pm 5.84$ & 0.200 \\
\hline $\mathrm{p}$-value & 0.001 & 0.138 & \\
\hline \multicolumn{4}{|c|}{$\begin{array}{c}\text { Surgery again, } \\
\mathrm{n}(\%)\end{array}$} \\
\hline Final & $8(80.0)$ & $6(85.7)$ & 0.761 \\
\hline \multicolumn{4}{|c|}{$\begin{array}{l}\text { Recommend } \\
\text { surgery, } n(\%)\end{array}$} \\
\hline Final & $8(80.0)$ & $7(100.0)$ & 0.208 \\
\hline \multicolumn{4}{|c|}{ Overall function } \\
\hline Preop & $4.30 \pm 2.36$ & $5.67 \pm 1.21$ & 0.212 \\
\hline Final & $8.57 \pm 1.51$ & $9.10 \pm 1.18$ & 0.199 \\
\hline$p$-value & $<0.001$ & 0.001 & \\
\hline \multicolumn{4}{|c|}{ Overall satisfaction } \\
\hline Final & $88.57 \pm 13.45$ & $92.14 \pm 9.06$ & 0.353 \\
\hline
\end{tabular}

Postoperative MRI or CTA was performed in 14 of 17 patients in the study (82.4\%): 10 patients (100.0\%) in the allogeneic group, and 4 patients (57.1\%) in the autologous group. (Table 5) The mean MRI follow-up was $15.00 \pm 3.94$ months (range 9-20) in the allogeneic group and $10.50 \pm 1.91$ months in the autologous group. One patient in the allogeneic group was excluded from analysis of structural integrity because rotator cuff repair was done only partially because of limited excursion. Therefore, 9 patients in the allogeneic group and 4 patients in the autologous group were included in the analysis. The retear rate did not differ significantly between the two groups: 33.3\% (3 of 9) in the allogeneic group, and $25.0 \%$ ( 1 of 4 ) in the autologous group $(p=0.764)$.

\begin{tabular}{|c|c|c|c|}
\hline Variable & Allogeneic $(n=10)$ & Autologous ( $n=7$ ) & $\mathrm{p}$-value \\
\hline \multicolumn{4}{|l|}{ ASES } \\
\hline Preop & $42.28 \pm 23.22$ & $63.06 \pm 17.49$ & 0.080 \\
\hline Final & $92.77 \pm 6.86$ & $98.65 \pm 2.00$ & 0.228 \\
\hline $\mathrm{p}$-value & $<0.001$ & 0.005 & \\
\hline \multicolumn{4}{|l|}{ Constant } \\
\hline Preop & $43.32 \pm 19.21$ & $56.70 \pm 12.35$ & 0.152 \\
\hline Final & $76.35 \pm 7.52$ & $82.03 \pm 4.96$ & 0.162 \\
\hline $\mathrm{p}$-value & 0.001 & 0.001 & \\
\hline
\end{tabular}

UCLA

\begin{tabular}{c|c|c|c}
\hline Preop & $26.43 \pm 18.27$ & $19.97 \pm 6.15$ & 0.421 \\
\hline Final & $32.29 \pm 3.50$ & $28.57 \pm 12.93$ & 0.808 \\
\hline p-value & 0.868 & 0.256 & \\
\hline \multicolumn{4}{|c}{ DASH } \\
\hline Preop & $49.75 \pm 27.16$ & $31.19 \pm 23.97$ & 0.167 \\
\hline Final & $6.19 \pm 6.65$ & $1.67 \pm 2.31$ & 0.190 \\
\hline p-value & 0.002 & 0.017 & \\
\hline
\end{tabular}

SST

\begin{tabular}{c|c|c|c}
\hline Preop & $5.10 \pm 3.38$ & $7.33 \pm 3.44$ & 0.225 \\
\hline Final & $11.29 \pm 1.25$ & $11.86 \pm 0.38$ & 0.263 \\
\hline p-value & 0.001 & 0.017 & \\
\hline SPADI & \multicolumn{5}{|}{} \\
\hline Preop & $54.91 \pm 28.62$ & $37.10 \pm 23.13$ & 0.219 \\
\hline Final & $6.14 \pm 5.65$ & $0.99 \pm 1.81$ & 0.308 \\
\hline p-value & 0.001 & 0.015 & \\
\hline
\end{tabular}

Data are expressed as mean \pm standard deviation.

Table 5. Retear Rates

\begin{tabular}{c|c|c|c}
\hline & Allogeneic $(\mathbf{n}=9)$ & Autologous $(\mathbf{n}=4)$ & p-value \\
\hline Retear & $3(33.3 \%)$ & $1(25.0 \%)$ & 0.764 \\
\hline
\end{tabular}

Data are expressed as $n$ (\%). PRP, Platelet-Rich Plasma 
Supraspinatus CSA taken immediately after surgery and one-year postoperative differed between the two groups; (Table 6) The CSA in the autologous group were greater than those in the allogeneic group at each time point. However, the change between the oneyear postoperative and immediate postoperative CSA was not significantly different between the two groups: $-67.42 \pm 58.75 \mathrm{~mm}^{2}$ in the allogeneic group, and $-49.05 \pm 58.57 \mathrm{~mm}^{2}$ in the conventional group $(p=0.373)$.

\begin{tabular}{|c|c|c|c|}
\hline $\begin{array}{c}\text { Cross-sectional area, } \\
\mathrm{mm}\end{array}$ & Allogeneic $(n=9)$ & Autologous ( $n=4)$ & $p$-value \\
\hline Immediately postoperative & $376.77 \pm 63.53$ & $478.66 \pm 99.63$ & 0.045 \\
\hline One-year postoperative & $309.35 \pm 69.04$ & $429.61 \pm 108.45$ & 0.032 \\
\hline$\Delta(\mathrm{PO} 1 \mathrm{yr}-\mathrm{ImPO})^{*}$ & $-67.42 \pm 58.75$ & $-49.05 \pm 58.57$ & 0.373 \\
\hline
\end{tabular}

Data are expressed as mean \pm standard deviation. ${ }^{*} \Delta(\mathrm{PO} 1 \mathrm{yr}-\mathrm{ImPO})$, a change of the cross-sectional area of the supraspinatus between the 1 -year postoperative measure and immediate postoperative measures.

\section{DISCUSSION}

This study showed that allogeneic PRP application in arthroscopic rotator cuff repair did not cause any adverse events, but demonstrated efficacy in clinical and structural outcomes comparable with autologous PRP for the first time, to our knowledge. While many studies have been performed to determine the effect of PRP in various injuries and diseases, $, 1,2,22$ most used autologous plasma, except for a few case reports. ${ }^{7,8,11,23}$ Except for one in vitro study which investigated the effect of allogeneic PRP compared to autologous PRP, ${ }^{24}$ no clinical studies have compared the safety and efficacy of allogeneic PRP over autologous PRP. Therefore, based on findings of this study, we suggest that allogeneic PRP may be a viable alternative when autologous PRP is not available or is less appropriate. However, before allogeneic PRP is used widely in the field of regeneration medicine, we also suggest that safety issues including bacterial or viral disease transmission and immune reaction be further clarified to guarantee patient safety, even though platelet transfusion via platelet pheresis is a safe and standard method undertaken within a highly-developed regulatory environment in blood donation services. For example, the use of a leukoreduction set may be an option, as in the current study, ${ }^{8}$ and some kinds of pathogen reduction technologies may merit consideration. ${ }^{25}$

An important cause of controversial results of PRP in rotator cuff repair derives from the wide variability of PRP used in these studies, ${ }^{26}$ resulting from different concentrations of cells, activation status, and application method through different preparation systems. Therefore, if these differences could be removed or avoided the real effects of PRP in rotator cuff repair could be more clearly elucidated. In this sense, allogeneic PRP may have several advantages over autologous PRP. First, as a standard blood bank product, a single-donor PRP is very easy to obtain, safe, and would be available in large quantities and incur less cost. $8,11,27$ Second, the collection process for this product is well-established and highly standardized with regard to the use of anticoagulant, separation and processing techniques, centrifugal force, and temperature and time, resulting in highly predictable amount of platelets, white blood cells, red blood cells, and fibrinogen. Third, standardized preparation process and products may allow researchers to investigate the effects of PRP more clearly, and the results from various studies could be compared more easily. Additionally, a more standardized method of obtaining allogeneic PRP, such as the platelet pheresis used in this study, would cause less activation of platelets during preparation than manual separation methods. ${ }^{27,28}$ Finally, the PRP could be prepared from younger patients in better health. Taken together, allogeneic PRP may have a great potential as a useful tool for biologic treatment strategies and could prove valuable clues to understand the mechanism of PRP, which has not yet occurred with autologous plasma.

One of the strengths of this study was that the patients in the comparison group were the corresponding donors of allogeneic PRP who also underwent the same surgery on the same day. This setting of the study eliminates some concerns about the potential variability of allogeneic PRP, surgical techniques, etc., thus making the results of the study more valuable. Another strength was that the allogeneic PRP was not manufactured and stored for a certain time, but freshly manufactured one day prior to surgery and was used the next day during the procedure, just like autologous PRP. This might be also helpful for removing any possible effects of storing PRP.

Limitations of the present study include; 1) small number of relatively heterogenic participants with regard to age, sex, and patients with partial-thickness rotator cuff tear in the control group, which may increase the risk of a type II error, 2) a lack of randomization, 3) incomplete characterization of PRP, such as absence of activation level or concentration of important growth factors, 4) low MRI follow-up rate to assess retearing, and 5) potential risk of adverse events related to transmission of viral and non-viral immunological infections despite HBV, HCV, HIV, and VDRL screening and use of a leukoreduction set.

\section{CONCLUSION}

Allogeneic PRP in arthroscopic rotator cuff repair did not cause any local or general complications and has an efficacy comparable to autologous PRP with respect to clinical and structural outcomes. This study provides the first evidence of the safety and efficacy of allogeneic PRP in arthroscopic rotator cuff repair. Further randomized clinical trials should be performed to support this preliminary study of allogeneic PRP for rotator cuff repair.

\section{ACKNOWLEDGEMENTS}

This work was supported by the SNUH Research Fund (No.04-20100230), and the Bio \& Medical Technology Development Program of the NRF, funded by the Korean government, MSIP (2011-0019773 \& 2015M3A9E6028412).

AUTHORS' CONTRIBUTIONS: Each author contributed individually and significantly to the development of the manuscript. CJ (0000-0002-6161$5442)^{*}$ was the main contributor in the drafting of the manuscript, and performed surgery. JS (0000-0002-6111-8067)* followed patients and gathered clinical data. SL (0000-0002-0637-923X)* prepared and characterized platelet-rich plasma. CJ and SS (0000-0003-4791-8671) evaluated the data for the statistical analysis, and reviewed the manuscript. *ORCID (Open Research and Contributor ID). 


\section{REFERENCES}

1. Filardo G, Kon E, Di Martino A, Di Matteo B, Merli ML, Cenacchi A, et al. Platelet-rich plasma vs hyaluronic acid to treat knee degenerative pathology: study design and preliminary results of a randomized controlled trial. BMC Musculoskelet Disord. 2012;13:229.

2. Jo $\mathrm{CH}$, Kim JE, Yoon KS, Lee JH, Kang SB, Lee JH, et al. Does platelet-rich plasma accelerate recovery after rotator cuff repair? A prospective cohort study. Am J Sports Med. 2011;39(10):2082-90.

3. Weber SC, Kauffman JI, Parise C, Weber SJ, Katz SD. Platelet-rich fibrin matrix in the management of arthroscopic repair of the rotator cuff: a prospective, randomized, double-blinded study. Am J Sports Med. 2013;41(2):263-70.

4. Randelli P, Arrigoni P, Ragone V, Aliprandi A, Cabitza P. Platelet rich plasma in arthroscopic rotator cuff repair: a prospective RCT study, 2-year follow-up. J Shoulder Elbow Surg. 2011;20(4):518-28.

5. Cai YZ, Zhang C, Lin XJ. Efficacy of platelet-rich plasma in arthroscopic repair of full-thickness rotator cuff tears: a meta-analysis. J Shoulder Elbow Surg. 2015;24(12):1852-9.

6. Malavolta EA, Gracitelli ME, Ferreira Neto AA, Assunção JH, Bordalo-Rodrigues $\mathrm{M}$, et al. Platelet-rich plasma in rotator cuff repair: a prospective randomized study. Am J Sports Med. 2014;42(10):2446-54.

7. Chen TM, Tzeng YS, Tsai JC, Burnouf T. Single-donor allogeneic platelet fibrin glue and osteoconductive scaffold in orbital floor fracture reconstruction. Ann Plast Surg. 2013;70(3):370-4.

8. Smrke D, Gubina B, Domanoviç D, Rozman P. Allogeneic platelet gel with autologous cancellous bone graft for the treatment of a large bone defect. Eur Surg Res. 2007;39(3):170-4.

9. Gandhi A, Doumas C, O'Connor JP, Parsons JR, Lin SS. The effects of local platelet rich plasma delivery on diabetic fracture healing. Bone. 2006;38(4):540-6.

10. Tyndall WA, Beam HA, Zarro C, O'Connor JP, Lin SS. Decreased platelet derived growth factor expression during fracture healing in diabetic animals. Clin Orthop Relat Res. 2003;(408):319-30.

11. Greppi N, Mazzucco L, Galetti G, Bona F, Petrillo E, Smacchia C, et al. Treatment of recalcitrant ulcers with allogeneic platelet gel from pooled platelets in aged hypomobile patients. Biologicals. 2011;39(2):73-80.

12. Scevola S, Nicoletti G, Brenta F, Isernia P, Maestri M, Faga A. Allogenic platelet gel in the treatment of pressure sores: a pilot study. Int Wound J. 2010;7(3):184-90.

13. Jo $\mathrm{CH}$, Shin JS, Park IW, Kim H, Lee SY. Multiple channeling improves the structural integrity of rotator cuff repair. Am J Sports Med. 2013;41(11):2650-7.

14. Jo $\mathrm{CH}$, Yoon KS, Lee JH, Kang SB, Lee JH, Han HS, et al. The effect of multiple channeling on the structural integrity of repaired rotator cuff. Knee Surg Sports Traumatol Arthrosc. 2011;19(12):2098-107.
15. Jo $\mathrm{CH}$, Yoon KS, Lee JH, Kang SB, Lee MC. The slippage-proof knot: a new, nonstacking, arthroscopic, sliding locking knot with a lag bight. Orthopedics.2007;30(5):349-50.

16. Sugaya H, Maeda K, Matsuki K, Moriishi J. Functional and structural outcome after arthroscopic full-thickness rotator cuff repair: single-row versus dual-row fixation. Arthroscopy. 2005;21(11):1307-16.

17. Zumstein MA, Jost B, Hempel J, Hodler J, Gerber C. The clinical and structural long-term results of open repair of massive tears of the rotator cuff. J Bone Joint Surg Am. 2008;90(11):2423-31.

18. Zanetti M, Gerber C, Hodler J. Quantitative assessment of the muscles of the rotator cuff with magnetic resonance imaging. Invest Radiol. 1998;33(3):163-70.

19. Jo $\mathrm{CH}$, Shin JS. Changes in appearance of fatty infiltration and muscle atrophy of rotator cuff muscles on magnetic resonance imaging after rotator cuff repair: establishing new time-zero traits. Arthroscopy. 2013;29(3):449-58.

20. Nove-Josserand L, Gerber C, Walch G. Lesions of the antero-superior rotator cuff, in Complex and revision problems in shoulder surgery. In: Warner JJP, Iannotti JP, Gerber C, editors. Philadelphia: Lippincott-Raven; 1997.p. 165-76.

21. Jo CH, Shin JS, Lee YG, Shin WH, Kim H, Lee SY, et al.Platelet-rich plasma for arthroscopic repair of large to massive rotator cuff tears: a randomized, single-blind, parallel-group trial. Am J Sports Med. 2013;41(10):2240-8.

22. Young Lae M, Sang Ho H, Young Kwan L, Yi Kyu P, Comparative studies of platelet-rich plasma (PRP) and prolotherapy for proximal biceps tendinitis. Clin Shoulder Elbow. 2011;14(2): 153-8.

23. Nikolidakis D, Meijer GJ, Jansen JA. Sinus floor elevation using platelet-rich plasma and beta-tricalcium phosphate: case report and histological evaluation. Dent Today. 2008;27(5):66, 68, 70; quiz 71.

24. Creeper F, Ivanovski S. Effect of autologous and allogenic platelet-rich plasma on human gingival fibroblast function. Oral Dis. 2012;18(5):494-500.

25. Klein HG, Anderson D, Bernardi MJ, Cable R, Carey W, Hoch JS, et al. Pathogen inactivation: making decisions about new technologies. Report of a consensus conference. Transfusion. 2007;47(12):2338-47.

26. Arnoczky SP, Delos D, Rodeo SA. What Is Platelet-Rich Plasma? Oper Tech Sports Med. 2011;19(3):142-8.

27. Zimmermann R, Reske S, Metzler P, Schlegel A, Ringwald J, Eckstein R. Preparation of highly concentrated and white cell-poor platelet-rich plasma by plaquetoforese. Vox Sang. 2008;95(1):20-5.

28. Zimmermann R, Jakubietz R, Jakubietz M, Strasser E, Schlegel A, Wiltfang J,et al. Different preparation methods to obtain platelet components as a source of growth factors for local application. Transfusion. 2001;41(10):1217-24. 